\title{
Pelatihan Manajemen Komunikasi Bisnis Dan Budaya Masyarakat Dalam Pemberdayaan Ekonomi Masyarakat Desa Ponggang Serangpanjang Subang
}

\author{
Dwinarko ${ }^{1,}{ }^{*}$, Tabrani Sjafrizal ${ }^{1}$, Nita Komala Dewi ${ }^{1}$, Ari Sulistyanto ${ }^{1}$, \\ Aan Widodo ${ }^{1}$ \\ ${ }^{1}$ Fakultas IImu Komunikasi, Universitas Bhayangkara Jakarta Raya; Jl. Raya Perjuangan, \\ Marga Mulya, Bekasi Utara, Jawa Barat 17121. Telp: 021-88955882, 889955883, e-mail: \\ dwinarko27@yahoo.com; tabrani.sjafrizal@dsn.ubharajaya.ac.id; \\ nita.komala@dsn.ubharajaya.ac.id; ari_sulistyanto@yahoo.com; \\ aan.widodo@dsn.ubharajaya.ac.id \\ * Korespondensi: e-mail: tabrani.sjafrizal@dsn.ubharajaya.ac.id
}

\begin{abstract}
Economic development that is carried out by activating Village-Owned Enterprises is explained in the Regulation of the Minister of Villages (Permendesa), Development of Disadvantaged Regions and Transmigration of the Republic of Indonesia Number 4 of 2015 concerning the Establishment, Management and Management and Amendment of Village-Owned Enterprises or so-called BUMDES. The purpose of establishing BUMDES in article 3 states that: (a) improving the village economy; (b) optimizing village assets to be useful for village welfare; (c) increasing community efforts in managing the economic potential of the village; (d) developing inter-village business cooperation plans and / or with third parties; (e) create market opportunities and networks that support citizens' general service needs; (f) open employment; (g) improving the welfare of the community through improving public services, growth and equitable distribution of the village economy; and (h) increase the income of the village community and the original income of the village. The existence of Village-Owned Enterprises as organizations that are business is a strategic step to build the community's economy. This strategic step must certainly be supported by village funds and management training and business communication that can encourage the achievement of the establishment of BUM Desa. Training on business communication management and community culture in the economic empowerment of the Ponggang Serangpanjang Subang village community aims to provide understanding and skills in improving the empowerment of rural communities through the development of tourism and MSMEs through the Village Owned Enterprises. The method used is in the form of business communication management training, with presentation techniques and training simulations for preparing proposals and business letters to the management and members of UMKM through the Ponggang Village Owned Enterprises. The output produced by the management and members can implement the principles of effective business communication management and can build village income sources by managing and creating jobs through tourism development, waste management, processing of agricultural products, plantations and fisheries.
\end{abstract}

Keywords: Strategy, Communication, Business, Empowerment, Society

\begin{abstract}
Abstrak
Pembangunan ekonomi yang dijalankan dengan mengaktipkan Badan Usaha Milik Desa dijelaskan dalam Peraturan Menteri Desa (Permendesa), Pembangunan Daerah Tertinggal dan Transmigrasi Republik Indonesia Nomor 4 Tahun 2015 tentang Pendirian, Pengurusan dan Pengelolaan dan Perubahan Badan Usaha Milik Desa atau yang disebut dengan BUMDES. Tujuan pendirian BUMDES dalam pasal 3 disebutkan bahwa: (a) meningkatkan perekonomian desa; (b) mengoptimalkan asset desa agar bermanfaat untuk kesejahteraan desa; (c) meningkatkan usaha masyarakat dalam pengelolaan potensi ekonomi desa; (d)
\end{abstract}


mengembangkan rencana kerja sama usaha antar desa dan atau / dengan pihak ketiga; (e) menciptakan peluang dan jaringan pasar yang mendukung kebutuhan layanan umum warga; $(\mathrm{f})$ membuka lapangan kerja; (g) meningkatkan kesejahteraan masyarakat melalui perbaikan pelayanan umum, pertumbuhan dan pemerataan ekonomi desa; dan (h) meningkatkan pendapatan masyarakat desa dan pendapatan asli desa. Keberadaan Badan Usaha Milik Desa sebagai organisasi yang sifatnya bisnis merupakan langkah strategis untuk membangun perekonomian masyarakat. Langkah strategis ini tentunya harus ditunjang dengan dana desa dan pelatihan manajemen serta komunikasi bisnis yang dapat mendorong tercapainya tujuan berdirinya BUM Desa. Pelatihan manajemen komunikasi bisnis dan budaya masyarakat dalam pemberdayaan ekonomi masyarakat desa Ponggang Serangpanjang Subang bertujuan memberikan pemahaman dan ketrampilan dalam meningkatkan pemberdayaan masyarakat desa melalui pembangunan parawisata dan UMKM melalui Badan Usaha Milik Desa.Metode yang digunakan berupa pelatihan manajemen komunikasi bisnis, dengan teknik presentasi dan simulasi pelatihan pembuatan proposal dan surat-surat bisnis kepada pengurus dan anggota UMKM melalui Badan Usaha Milik Desa Ponggang.Luaran yang dihasilkan pengurus dan anggota dapat menjalankan prinsip-prinsip manajemen komunikasi bisnis efektif dan dapat membangun sumber pendapatan desa dengan mengelola dan menciptakan lapangan kerja melalui pembangunan pariwisata, pengolahan limbah, pengolahan hasil pertanian, perkebunan dan perikanan.

Kata Kunci: Strategi, Komunikasi, Bisnis, Pemberdayaan, Masyarakat

\section{Pendahuluan}

Pemerataan pembangunan dalam nawacita pemerintahan Presiden Joko Widodo dan Yusuf Kala tidak hanya pembangunan infrastruktur tetapi pembangunan ekonomi menyeluruh ke pelosok Indonesia.Pembangunan ekonomi yang dijalankan dengan mengaktipkan Badan Usaha Milik Desa dijelaskan dalam Peraturan Menteri Desa (Permendesa), Pembangunan Daerah Tertinggal dan Transmigrasi Republik Indonesia Nomor 4 Tahun 2015 tentang Pendirian, Pengurusan dan Pengelolaan dan Perubahan Badan Usaha Milik Desa atau yang disebut dengan BUMDES(Indonesia, 2017). Tujuan pendirian BUMDES dalam pasal 3 disebutkan bahwa: (a) meningkatkan perekonomian desa; (b) mengoptimalkan asset desa agar bermanfaat untuk kesejahteraan desa; (c) meningkatkan usaha masyarakat dalam pengelolaan potensi ekonomi desa; (d) mengembangkan rencana kerja sama usaha antar desa dan atau / dengan pihak ketiga; (e) menciptakan peluang dan jaringan pasar yang mendukung kebutuhan layanan umum warga; (f) membuka lapangan kerja; (g) meningkatkan kesejahteraan masyarakat melalui perbaikan pelayanan umum, pertumbuhan dan pemerataan ekonomi desa; dan (h) meningkatkan pendapatan masyarakat desa dan pendapatan asli desa(Indonesia, 2017).

Keberadaan Badan Usaha Milik Desa sebagai organisasi yang sifatnya bisnis merupakan langkah strategis untuk membangun perekonomian masyarakat. Langkah strategis ini tentunya harus ditunjang dengan dana desa dan pelatihan manajemen serta komunikasi bisnis yang dapat mendorong tercapainya tujuan berdirinya BUM Desa.Menurut Kemendes PDTT dijelaskan bahwa dana desa telah menunjukkan capaian pembangunan yang signifikan di pedasaan. Pemerintah telah menyalurkan dana desa mencapai Rp. 187 triliun(Reza, 2019). Tahun 2018 sebesar Rp. 60 triliun yang disalurkan kepda 74.957 desa(Reza, 2019). 
Tahun 2018 ditargetkan mengentaskan desa tertinggal sebanyak 15 ribu desa.Menurut Sekretaris Jenderal Kemendesa PDTT, tahun 2016 tercatat ada 18 ribu BUM Desa dan Tahun 2017 sampai Oktober meningkat menjadi sekitar 22 ribu BUMDes(Sartono, 2018). Dari 22 ribu BUMDes tersebut rata-rata masih berkembang, dan baru sekitar 50 BUMDes yang sudah maju(Sartono, 2018). Sebagai contoh BUMDes yang onzetnya bersih di atas Rp 500 juta. Ponggok (Klaten) onzetnya Rp 12 miliar, di Karanggrejek (Gunungkidul) mencapai 700 juta(Sartono, 2018).

Merujuk data perkembangan BUM Desa yang telah mendapatkan keuntungan dan omzet bersih tersebut, tentunya perlu dilakukan sosialisasi dan pelatihan-pelatihan manajemen pengelolaan terhdap BUM Desa yang masih berkembang dan belum berkembang.Tujuan BUM Desa sangat jelas yaitu untuk meningkatkan kesejahteraan karyawan, dan pengelola yang memiliki asas untuk pemberdayaan masyarakat.Artinya BUMDES sebagai organisasi bisnis harus dikelola secara efektif dengan menentukan strategi komunikasi bisnis dan manajemen yang handal.Program pemberdayaan BUMDES didukung penuh oleh dana desa dalam program pembangunan pemerintah pusat yang berusaha untuk membangunan secara seimbang, yaitu baik pembangunan infrastruktur maupun pembangunan ekonomi melalui pemberdayaan sumber daya manusia dan alam yang ada di lingkungan masyarakat desa.

Pada prinsipnya hadirnya BUMDes tidak boleh mematikan usaha masyarakat setempat. BUMDes tidak boleh jadi predator masyarakat.BUMDes itu untuk kepentingan bersama, bukan untuk merugikan. BUMDes harus mampu menjadi wadah yang merangkul dan mengembangkan potensi dan usaha masyarakat desa," pungkasnya(Bramantyo, 2017). Perkembangan BUM Desa yang sudah mencapai 22 ribu desa dan 50 yang sudah maju tersebut, harus menjadi motivasi dan mendorong kepada Desa yang belum siap untuk mengelola BUM Desa dan salah satunya di Desa Ponggang Kecamatan Serangpanjang Subang. Manajemen dan pengurus BUM Desa masih belum bisa menentukan Anggaran Dasar Rumah Tangga dan program kerja mereka.Padahal banyak potensi yang harus dikembangkan, seperti, perkembangan pariwisata, budi daya perikanan, perkebunan, pertanian, dan sebagainya.

Berdasarkan penjelasan tersebut di atas, dapat dikatakan bahwa BUM Desa merupakan bentuk organisasi atau perusahaan yang berafiliasi pada nilai bisnis, yang bertujuan untuk memberikan kesejahteraan kepada para anggota, pengurus dan masyarakat.Artinya BUM Desa merupakan organisasi yang berorientasi pada profit/keuntungan dan perlu ditunjang dengan kemampuan manajemen bisnis yang efektif dan berkualitas.

Menurut Siswanto, organisasi sebagai entitas politik yaitu: (1) organisasi adalah koalisi yang terdiri dari berbagai individu dan kelompok dengan berbagai kepentingan, (2) dalam organisasi selalu ada potensi perbedaan menyangkut kepribadian, keyakinan, kepentingan, sikap, persepsi, dan minat dari para anggotanya, (3) kekuasaan memainkan peranan penting dalam memperebutkan sumber daya, (4) tujuan organisasi, pengambilan keputusan dan proses manajemen lainnya adalah hasil dari bargaining, negosiasi, dan brokering dari berbagai faksi 
peserta, (5) karena keterbatasan sumber daya dan setiap aktor berebut kepentingan, maka konflik adalah wajar (natural) dalam kehidupan organisasi(Siswanto, 2007). Organisasi menurut McShane \& Von Glinov dalam Feriyanto \& Triana, adalah sekelompok masyarakat kecil yang saling bekerja sama untuk mencapai suatu tujuan dan sekelompok orang yang bekerja sama dan saling bergantung untuk mencapai beberapa tujuan(Feriyanto, et al, 2015).

Guna menjalankan BUMDES yang kompetitip diperlukan adanya upaya komunikasi yang efektif dan strategi pengelolaan bisnis yang professional. Menurut Hovland dalam Feriyanto \& Triana menyatakan bahwa komunikasi adalah upaya yang sistematis untuk merumuskan secara tegas asas-asas penyampaian serta pembentukan pendapat dan sikap (Feriyanto, et al, 2015). Upaya dalam menjalankan organisasi BUMDES tersebut dapat digerakan dengan melakukan komunikasi.Komunikasi dimaksudkan sebagai alat untuk pengorganisasi bisnis yang efektif dan strategi bisnis. Menurut Brennan dalam Irwansyah, komunikasi bisnis merupakan struktur yang dinamis dari pertukaran gagasan, perasaan dan usaha bersama untuk mendapatkan keuntungan(Irwansyah, 2017).

BUMDES yang berjalan di masyarakat Indonesia, merupakan program pemerintah yang berjalan mulai tahun 2014, sehingga keberadaan BUMDES masih banyak yang belum berkembang dan belum berjalan. Hal ini karena masih banyak kendala yang harus diperbaiki, yaitu: faktor SDM, faktor budaya, faktor kemampuan SDM dan faktor kepentingan politik lainnya.Merujuk pada penjelasan tersebut dapat penulis menyimpulkan bahwa untuk menjalankan BUM Desa secara professional dibutuhkan adanya manajemen dan komunikasi bisnis yang efektif dan strategis bisnis yang ditetapkan.

Target luaran yang diharapkan setelah pelatihan manajemen komunikasi bisnis BUM Desa ini adalah sebagai berikut:

Tabel 1. Target Luaran Pelatihan Manajemen Komunikasi

\begin{tabular}{|c|c|c|}
\hline No. & Kegiatan Pelatihan & $\begin{array}{c}\text { Target Luaran Pada Pengurus dan Anggota BUM Desa Ponggang } \\
\text { Serangpanjang Subang }\end{array}$ \\
\hline 1. & $\begin{array}{l}\text { Pelatihan Manajemen Komunikasi } \\
\text { Bisnis BUM Desmelalui pengelolaan } \\
\text { aset-aset desa dan penggunaan dana } \\
\text { desa }\end{array}$ & $\begin{array}{l}\text { a. Meningkatkan kuantitas dan kualitas pemberdayaan organisasi } \\
\text { BUM Desa. } \\
\text { b. Mampu mengorganisir BUM Desa dengan kegiatan } \\
\text { perencanaan, pengorganisasi, melakukan tindakan dan } \\
\text { pengawasan. }\end{array}$ \\
\hline 3 & Hasil Pelatihan & $\begin{array}{ll}\text { a. } & \text { Penulisan Jurnal } \\
\text { b. } & \text { Kerja sama antar lembaga desa dengan Universitas Bhayangkara, } \\
\text { kementerian desa, kabupaten dan propinsi dalam meningkatkan } \\
\text { ekonomi masyarakat desa dan membuka lapangan kerja }\end{array}$ \\
\hline
\end{tabular}

Menurut Purwanto, komunikasi bisnis adalah komunikasi yang digunakan dalam dunia bisnis, yang mencakup komunikasi verbal dan nonverba I(Djoko, 2003). Pengelolaan BUM Desa memerlukan pelatihan manajemen dan komunikasi bisnis yang efektif untuk organisasi dan mengelola BUM Desa, perlu adanya pembinaan dan sosialisasi dari BUM Desa yang telah 
berhasil kepada BUM Desa yang masih berkembang dan belum bergerak, sehingga visi misi dan tujuan BUM Desa dapat tercapai dan dinikmati oleh semua (74. 957) desa yang tersebar di seluruh Indonesia.

\section{Metode Pelaksanaan}

Kegiatan ini dilaksanakan Desa Searngpanjang Subang yang berlangsung selama 3 bulan dengan tahapan kegiatan seperti Gambar 1 berikut ini.

Tahap Pelaksanaan Pengabdian Kepada Masyarakat (PKM)
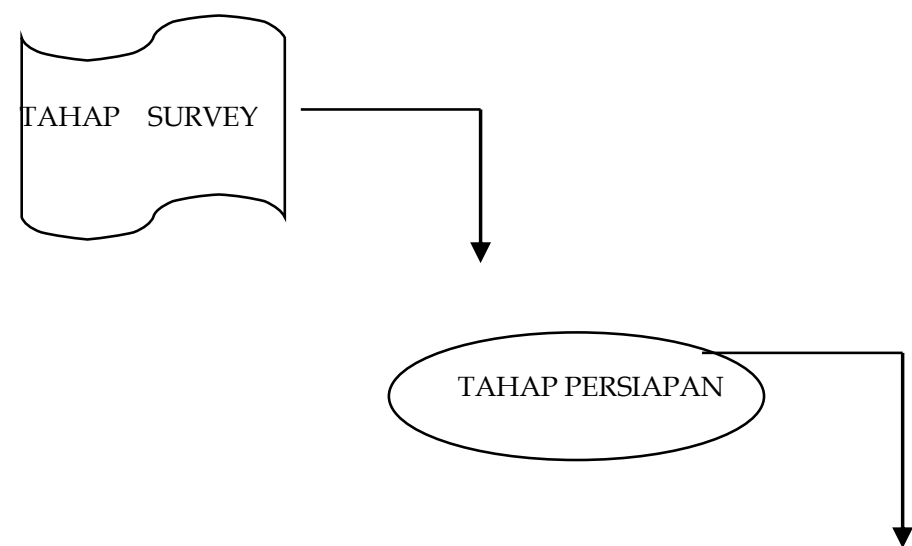

TAHAP

PELAKSANAAN

PENDAMPINGAN

DAN MONITORING

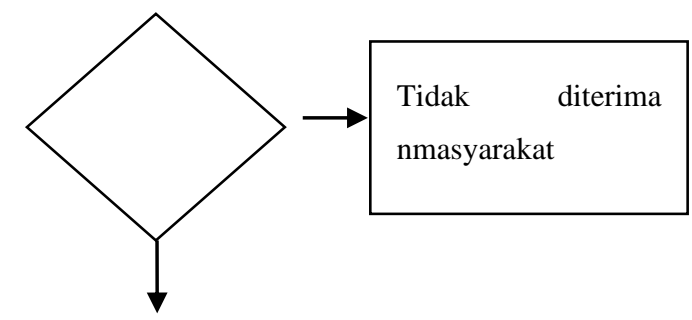

DITERIMA MASYARAKAT

Gambar 1. Tahap Kegiatan PKm pelatihan manajemen dan komunikasi bisnis yang efektif untuk organisasi dan mengelola BUM Desa.

Dalam pelaksanaan kegiatan pengabdian kepada masyarakat kami menggunakan metode pelaksanaan sebagai berikut: 1) Membuat proposal rencana kegiatan pengabdian kepada 
masyarakat. 2) Mengajukan proposal dan kemudian tim abdimas direviewer oleh tim reviewer yang terkait dengan proposal pengajuan. 3) Mengedit proposal hasil reviewer. 4) Ketua Abdimas menandatangani surat perjanjian kontrak dalam rangka pencairan dana pengabdian kepada masyarakat, dalam rangka pencairan dana sebesar 50\% nya. 5) Melakukan survey lapangan untuk meninjau kesiapan sarana prasarana pelatihan yang akan dilaksanakan. 6) Membuat dan memperbanyak modul-modul materi yang akan dipaparkan dalam Pelatihan Manajemen Komunikasi Bisnis BUM Desa antara lain: a) Modul "Manajemen Komunikasi Bisnis" oleh DR. Dwinarko, Drs, MM, MH; b) Modul "Pemberdayaan Budaya Organisasi dan Strategi Bisnis" oleh Tabrani Sjafrizal, S. Sos, M.I. Kom. c) Modul "Teknik pembuatan proposal dan surat-menyurat Bisnis" oleh Nita Komala Dewi, S.I. Kom., M.M dan DR. Ari Sulistyanto, S. Sos, M.I. Kom, serta DR. Aan Widodo, S.I. Kom, M.I. Kom. 7) Mempersiapkan draft surat keterangan telah melaksanakan kegiatan pengabdian kepada masyarakat beserta sertifikatsertifikatnya. 8) Mempersiapkan daftar susunan acara, daftar kehadiran peserta, konsumsi, peralatan dan bahan habis pakai sebagai dokumentasi.

\section{Waktu dan Tempat Pelaksanaan Kegiatan Pengabdian Kepada Masyarakat.}

Kegiatan Pengabdian Kepada Masyarakat dengan tema "Pelatihan Manajemen Komunikasi Bisnis dan Budaya Masyarakat Dalam Pemberdayaan Ekonomi Masyarakat Desa Ponggang Serangpanjang Subang" dilaksanakan 2 hari, pada:

Hari/Tanggal : :Sabtu dan Minggu ke I Bulan Agustus 2019

Waktu $\quad: 08.30-16.30$ WIB

Bertempat : :GOR Desa Ponggang Serangpanjang Subang Jawa Barat

Kegiatan ini dihadiri oleh 20 orang peserta. Kegiatan ini dimulai dengan pembacaan susunan acara oleh DR. Ari Sulistyanto, S.Sos,M.I.Kom sebagai MC. Selanjutnya sambutan dari Ketua Pelaksana Abdimas Fikom Ubhara Jaya yaitu DR. Drs. Dwinarko, MM, MH menyampaikan amanatnya, bahwa kegiatan pengabdian kepada masyarakat ini merupakan realisasi dari salah unsur Tri Dharma Perguruan Tinggi, yaitu pengajaran, penelitian, dan pengabdian kepada masyarakat.

Adapun tujuan dari kegiatan pengabdian kepada masyarakat kali ini, yaitumenyumbangkan pemikiran kepada masyarakat dalam rangka memberikan solusi dan pelatihan mengenai Manajemen Komunikasi Bisnis dan budaya masyarakat, dalam Pemberdayaan ekonomi BUM Desa Ponggang Serangpanjang Subang, guna peningkatan kesejahteraan masyarakat desa.

Sambutan berikutnya oleh Bapak Kepala Desa Ponggang, yaitu Bapak Asep Suryana, mengatakan kami mewakili masyarakat Desa Ponggang sangat, berterima kasih sekali kepada Tim Abdimas Dosen Tetap Fikom Universitas Bhayangkara Jakarta Raya, yang telah menyempatkan diri datang jauh-jauh dari Bekasi ke Desa Ponggang, guna berbagi 
pengetahuan tentang Manajemen Komunikasi Bisnis dan Budaya Masyarakat, dalam Pemberdayaan ekonomi BUM Desa Ponggang Serangpanjang Subang. Kami menyambut dengan sangat senang sekali kegiatan ini, karena dengan adanya kegiatan ini, diharapkan dapat memberikan wawasan dan pengetahuan yang bermanfaat sekali dalam mmenjalankan BUMDes ke depan.

Untuk itu diharapkan para peserta mengikuti acara pelatihan ini dengan serius dan ikhlas serta sungguh-sungguh.Sesi pelatihan pertama diisi oleh DR.Drs.Dwinarko,MM,MH, mengemukakan Perkembangan BUM Desa yang sudah mencapai 22 ribu desa dan 50 yang sudah maju tersebut, harus menjadi motivasi dan mendorong kepada Desa yang belum siap untuk mengelola BUM Desa dan salah satunya di Desa Ponggang Kecamatan Serangpanjang Subang.

Manajemen dan pengurus BUM Desa masih belum bisa menentukan Anggaran Dasar Rumah Tangga dan program kerja mereka.Padahal banyak potensi yang harus dikembangkan, seperti, perkembangan pariwisata, budi daya perikanan, perkebunan, pertanian, dan sebagainya.Berdasarkan penjelasan tersebut di atas, dapat dikatakan bahwa BUMDesa merupakan bentuk organisasi atau perusahaan yang berafiliasi pada nilai bisnis, yang bertujuan untuk memberikan kesejahteraan kepada para anggota, pengurus dan masyarakat.Artinya BUM Desa merupakan organisasi yang berorientasi pada profit/keuntungan dan perlu ditunjang dengan kemampuan manajemen bisnis yang efektif dan berkualitas.Guna menjalankan BUMDES yang kompetitip diperlukan adanya upaya komunikasi yang efektif dan strategi pengelolaan bisnis yang professional.Upaya dalam menjalankan organisasi BUMDES tersebut dapat digerakan dengan melakukan komunikasi.Komunikasi dimaksudkan sebagai alat untuk pengorganisasi bisnis yang efektif dan strategi bisnis.

Maka guna menjalankan BUM Desa secara professional, dibutuhkan adanya manajemen dan komunikasi bisnis yang efektif serta strategis bisnis yang ditetapkan, mulai dari perencanaan, pengorganisasian, pelaksanaan, pengawasan jalannya acara dan terakhir evaluasi.Sesi kedua Tabrani Sjafrizal,S.Sos,M.I.Kom, mengemukakan bahwa peranbudaya organisasidalam suatu organisasi sangat penting sekali, dikarenakan pada komunikasi organisasi,terutama berkenaan dengan transaksi yang terjadi dalam lingkungan internal organisasi yang terdiri dari organisasi dan dan kulturnya, dan antara organisasi itu dengan lingkungan eksternalnya.

Adapun yang dimaksud dengan kultur organisasi, adalah pola kepercayaan dan harapan dari anggota organisasi, yang menghasilkan norma-norma, yang membentuk tingkah laku individu dan kelompok dalam organisasi.Budaya dipelajari dan membantu manusia dalam usaha mereka berinteraksi dan berkomunikasi dengan orang lain dalam masyarakat.Ketika nilai dan kepercayaan dalam budaya berbeda, beberapa orang memiliki masalah penyesuaian. Jika hal ini tidak diantisipasi, maka akan menjadi penyebab kegagalan usaha dalam organisasi yang disebut "Culture Shock".Sedangkan yang terkait dengan strategi bisnis menurut Oktaviani Satyaningtyas, kita dapat melakukan atau menerapkan dengan 5 langkah, yaitu: 1) Ambil waktu 
untuk menganalisa performa bisnis. 2). Pertimbangkan untuk melakukan Product line extension. 3). Membuat target pencapaian bisnis di masa depan. 4) Berpatisipasi dalam pameran bisnis. 5) Membuka cabang.

Sesi ketiga DR.Ari Sulistyanto,S.Sos, mengemukakan bahwa surat-menyurat bisnis dan proposal bisnis, merupakan dua media komunikasi yang sering digunakan di dalam berbagai kegiatan bisnis. Surat menyurat di dalam bisnis terdiri dari dua pendekatan, yaitu pendekatan langsung dan tidak langsung. Adapun untuk masing-masing pendekatan tersebut dapat digambarkan sebagai berikut:

Memilih Pendekatan Organisasional, sebagai berikut:

\section{a. Pendekatan Tak Langsung}

Pendekatan tak langsung merupakan pendekatan yang paling familier atau lazim digunakan untuk penulisan pesan-pesan yang mempunyai dampak kurang menyenangkan kepada audiens (bad-news).Barangkali Anda sering menggunakan pendekatan ini untuk menghindari kekecewaan orang lain.Dalam pendekatan tak langsung terdapat 4 bagian penting, yaitu (1) pembuka, (2) alasan pendukung untuk keputusan-keputusan negatif, (3) pernyataan bad-news, dan (4) penutup yang positif dan bersahabat.

Penjelasan:

1). Pembuka

Pada tahap pembuka ini Anda menempatkan audiens pada situasi yang netral melalui pernyataan tanpa beban bagi audiens Anda. Pernyataan netral yang mengantarkan pernyataan bad-news sering disebut dengan buffer.

Dalam menulis paragraf pembuka, ada beberapa hal yang perlu dihindari,antara lain: Mengatakan "Tidak!", Penggunaan frase yang tidak relevan, Permohonan maaf, dan Penulisan buffer yang terlalu panjang.

2). Alasan

Memberikan alasan mengapa suatu keputusan tersebut harus diambil/ terjadi, sebelum menyatakan apa keputusan yang sebenarnya.

Contoh, ketika Anda ingin menolak pengajuan kredit seorang nasabah, Anda dapat memberikan penjelasan kepada mereka, bahwa apabila pengajuan tersebut dipenuhi akan berakibat beban yang ditanggungnya menjadi semakin berat di kemudian hari.

3). Bad-News

Setelah Anda memberikan alasan "mengapa" suatu keputusan harus diambil, pada tahapan ini Anda dapat secara langsung mengemukakan apa keputusan yang diambil, seperti keputusan menolak permintaan kredit.

4). Penutup

Setelah Anda menyampaikan pesan-pesan yang kurang menyenangkan, tahap berikutnya adalah memberikan kata penutup yang bersifat positif, hangat, bersahabat, dan lebih menyenangkan. Disamping itu, Anda dapat mengusulkan suatu cara pemecahan masalah 
yang dihadapi oleh audiens Anda. Dan yang lebih penting lagi adalah berikan kesan yang baik kepada audiens Anda.

\section{b. Pendekatan Langsung}

Suatu pesan yang kurang menyenangkan yang diorganisasikan dengan pendekatan langsung akan diawali dengan suatu pernyataan bad-news, selanjutnya diikuti dengan berbagai alasan yang mendukungnya, dan diakhiri dengan penutup yang bersahabat.

Walaupun relatif jarang diterapkan, pendekatan ini memiliki suatu keuntungan yaitu audiens hanya memerlukan waktu yang relatif singkat untuk sampai pada ide pokoknya yaitu bad-news

Suatu pendekatan organisasional pendekatan langsung dapat diterapkan jika: a) Penerima pesan lebih menyukai pesan langsung ke poin yang dituju. b) Pesan tersebut mempunyai pengaruh yang kecil terhadap si penerima pesan. c). Pesan disampaikan secara empati.

Setelah semua pembicara mengemukakan seluruh materinya, maka tibalah pada acara puncaknya, yaitu sesi praktek. Untuk sesi praktek manajemen komunikasi bisnis dan budaya masyarakat dalam pemberdayaan ekonomi masyarakat Desa Ponggang Serangpanjang Subang ini, Tim Abdimas UBJ memilih bagaimana cara penerapan manajemen komunikasi bisnis pada masing-masing usaha. Pertama-tama para peserta diminta untuk membentuk 4 kelompok.

Setelah itu, kepada para peserta (berkelompok) dimohon bagaimana menerapkan manajemen komunikasi bisnis pada masing-masing usaha, dengan tema ditentukan oleh para peserta itu sendiri. Untuk tema, cukup 1 tema untuk 1 kelompok. Adapun waktu yang diberikan oleh tim abdimas UBJ kepada para peserta dalam menyelesaikan secara berkelompok untuk menyelesaikan tugas praktek ini adalah 1 jam.

Setelah 1 1/2 jam berlalu, para peserta (berkelompok) menyerahkan hasilnya kepada tim abdimas UBJ untuk dikoreksi. Selanjutnya tim abdimas UBJ memberikan penilaian atas hasil praktek tersebut. Adapun hasil - hasil penilaian tersebut adalah sebagai berikut:

Tabel 2. Daftar Hasil Penilaian Oleh Tim Abdimas UBJ

\begin{tabular}{llccl}
\hline \multicolumn{1}{c}{ No. } & NILAI & KETERANGAN & CATATAN OLEH TIM ABDIMAS UBJ \\
\hline $\begin{array}{l}\text { 1. Pembuatan Pupuk Kompos } \\
\text { Organik }\end{array}$ & 80 & Juara 1 & Tidak ada \\
\hline $\begin{array}{l}\text { Kegiatan Badan Usaha Milik } \\
\text { Desa Jembar }\end{array}$ & 75 & Juara 2 & $\begin{array}{l}\text { - Latar belakang permasalahan tidak ada } \\
\text { 2. Anggaran yang dibutuhkan secara keseluruhan }\end{array}$ \\
& & & $\begin{array}{l}\text { - belum dibuat secara rinci. } \\
\end{array}$
\end{tabular}




\begin{tabular}{|c|c|c|c|c|}
\hline No. & PERIHAL & NILAI & KETERANGAN & CATATAN OLEH TIM ABDIMAS UBJ \\
\hline 3. & 10 program PKK & 70 & Juara 3 & $\begin{array}{l}\text { - Latar belakang permasalahan tidak ada } \\
\text { - Anggaran yang dibutuhkan secara keseluruhan } \\
\text { belum dibuat secara rinci }\end{array}$ \\
\hline 4. & $\begin{array}{l}\text { Kegiatan } \\
\text { Posyandu }\end{array}$ & 65 & Juara 4 & $\begin{array}{l}\text { - Latar belakang permasalahan tidak ada dan rincian } \\
\text { lainnya terlalu sederhana. }\end{array}$ \\
\hline
\end{tabular}

Sumber: Hasil Pelaksanaan (2020)

\section{Hasil dan Pembahasan}

Berikut merupakan dokumentasi kegiatan pembekalan:

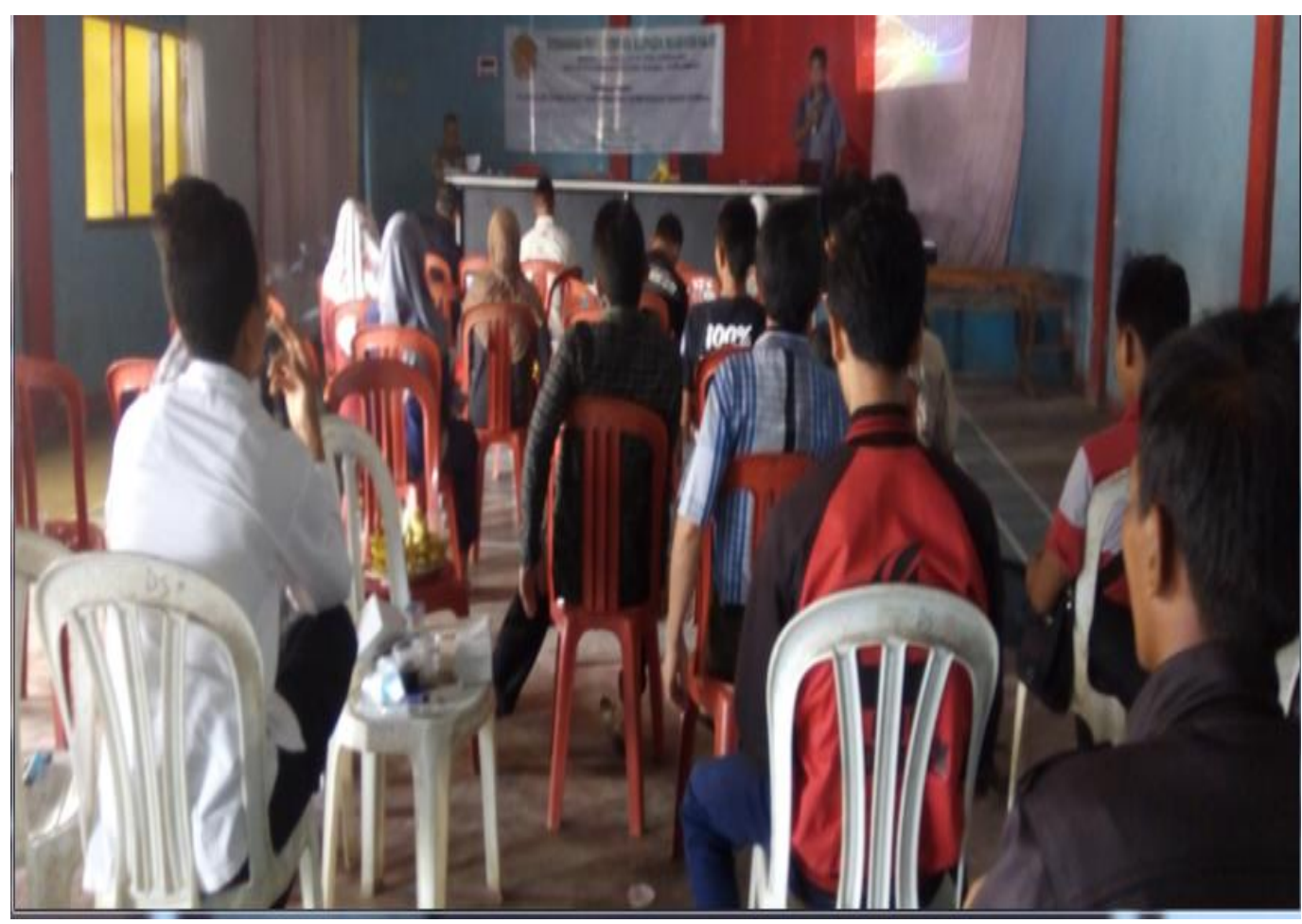

Sumber: Hasil Pelaksanaan (2020)

Gambar 2. Daftar Hasil Penilaian Oleh Tim Abdimas UBJ

Indikator keberhasilan kegiatan PKm secara normatif jika rencana kegiatanmencapai hasil yang sama dengan pelaksanaan di lapangan, maka dapat dikatakan sesuai dengan yang diharapkan atau berhasil. Berikut merupakan beberapa indikator capaian penyelenggaraan kegiatan PKm yaitu 
a. Materi pelatihan

Materi pelatihan direncanakan sesuai dengan materi pelatihan yang telah disiapkan oleh nara sumber, dan hasil ini sesuai dengan diberikan saat praktek di lapangan. Pemberian materi disampaikan dalam bentuk powerpoint dan hard copy materi pelatihan yang diberikan kepada setiap peserta.

b. Jumlah peserta pelatihan

Jumlah peserta yang semula direncanakan sekitar 30 orang, tetapi dalam kenyataannya pelatihan diikuti oleh 20 orang, berarti dari sisi jumlah peserta belum tercapai keberhasilan.

c. Perhatian peserta

Intensitas perhatian dan kehadiran dari awal acara sampai berakhir acara kegiatan, menunjukkan mereka telah mengikuti acara kegiatan dari awal acara sampai acara selesai dengan baik. Hal ini juga menunjukkan suatu keberhasilan kegiatan.

d. Bahan pelatihan

Bahan pelatihan berupa modul materi, alat, makan dan minum, serta snack selama pelatihan berlangsung disediakan oleh tim PKm.

\section{Kesimpulan}

Kegiatan pengabdian masyarakat berupa pelatihan manajemen dan komunikasi bisnis yang efektif untuk organisasi dan mengelola BUM Desa, berjalan dengan lancer, dan diikuti oleh hampir seluruh peserta. Pengetahuan peserta mengalami peningkatan setelah mengikuti pelatihan, seperti terlihat pada tabel daftar hasil penilain oleh tim Abdimas UBJ. Berdasarkan pelatihan PKm yang telah dilakukan, maka saran yang direkomendasikan, yaitu masih diperlukan pelatihan-pelatihan lainnya seperti di bidang pemasaran, yang mendukung aktivitas pengurus BUMDesDesa Ponggang Serangpanjang Subang Jawa Barat.

\section{Ucapan Terima Kasih}

Penulis mengucapkan terima kasih kepada para pengurus BUMDes Desa Ponggang Serangpanjang Subang Jawa Barat, dan Universitas Bhayangkara Jakarta Raya melalui Lembaga Penelitian, Pengabdian Kepada Masyarakat \& Publikasi (LPPMP) yang telah memberikan dana untuk terlaksananya kegiatan pengabdian masyarakat ini. Terima kasih juga kepada para pegawai dari pimpinan hingga staf Kantor Kepala Desa Ponggang SerangPanjang Subang Jawa Barat, serta juga kepada seluruh dosen Program Studi S1 Fakultas IImu Komunikasi UBJ.

\section{Daftar Pustaka}

Bramantyo. (2017, November). Potensial Berkembang, Ada BUMDes yang Omzetnya Rp12 Miliar/Tahun. Okezon.Com. 
Djoko, P. (2003). Komunikasi Bisnis. In Erlangga. https://doi.org/10.1186/bcr3053.

Feriyanto, Andri \& Shyta, E. T. (2015). Pengantar Manajemen 3 in 1. Kebumen: Mediatera.

Indonesia, R. Peraturan Menteri Desa, Pembangunan Daerah Tertinggal, Dan Transmigrasi Republik Indonesia. , https://www.jogloabang.com/users/jogloabang § (2017).

Irwansyah. (2017). Komunikasi Bisnis. Mitra Wacana Media.

Reza, P. (2019, April). Kemendes Gelar Forum Tematik Badan Koordinasi Kehumasan. Liputan6.Com.

Sartono. (2018). Pelatihan Pengelola Menjadi Pengungkit Perkembangan Bumdes dalam Menjalankan Usahanya. Detik.Com.

Siswanto. (2007). Pengantar Manajemen. Jakarta: PT. Bumi Aksara. 